\title{
Dosificación de hormigón reforzado con \\ fibras de acero
}

\author{
Mix design of steel fiber \\ reinforced concrete \\ EDUARDO MORENO ALMANSA Y MANUEL FERNÁNDEZ CÁNOVAS \\ Depto. de Ingeniería Civil-Construcción. E.T.S. de Ingenieros de Caminos, Canales y \\ Feccha de recepción: 24-IV-97 \\ Puertos. Univ. Politécnica de Madrid \\ Fecha de aceptación: 18-VI-97 \\ ESPAÑA
}

\section{RESUMEN}

El objetivo de una correcta dosificación de hormigón reforzado con fibras metálicas (HRFA) es conseguir una mezcla que mantenga una docilidad, homogeneidad, durabilidad y resistencia adecuadas a su uso.

A continuación se estudian las variables que definen una dosificación de HRFA, asi como su influencia en las propiedades del HRFA fresco y endurecido.

Se presta una especial atención al hormigón proyectado ya que es la principal aplicación de las fibras metálicas en España, seguido por la construcción de pavimentos.

\section{SUMMARY}

Mix design of steel fiber reinforced concrete (SFRC) is concerned with achieving a workability, homogeneity, durability and strength suitable for its use.

Variables defining any mix design of SFRC are commented below, as well as their influence on some properties of fresh and hardened SFRC.

A special attention is paid to shotcrete, since it's the main use of steel fibers in Spain now, followed by paving construction.

\section{CEMENTO Y AGUA}

El cociente agua/cemento tiene una relación conocida con la capacidad mecánica y la durabilidad del hormigón. El volumen de agua que entra en dicha fracción es el agua efectiva, que incluye la total menos la absorbida por los áridos si éstos tienen, en el hormigonado, una humedad inferior a la propia de equilibrio; si es superior, éstos aportarán agua a la masa.

La adición de fibras metálicas no impone el uso de un determinado tipo de cemento. Esta elección depende de los mismos condicionantes que en otros diseños: resistencias a corto y largo plazo, resistencia en ambientes agresivos, bajo calor de hidratación, tiempo de fraguado, retracción plástica y, a largo plazo, adherencia a la base en el caso de hormigón o mortero

\section{CEMENT AND WATER CONTENT}

Watericement ratio has a well known influence on mechanical strength and durability of concrete. If aggregates have a moisture smaller than their equilibrium moisture (or SSD moisture), water content included in this ratio will be the water added on batching plus that added by components of concrete minus that absorbed by aggregates. If moisture of aggregates is larger, they will supply more water to the mix.

Fibers addition don 't compel to use any type of cement. This selection depends on the same conditions as any other design: mechanical strength at early and long ages, strength against agressive environment, low heat hydration, setting time, plastic and drying shrinkage, adhesion to support for shotcrete. interaction with admixtures or additions, etc... Blast 
proyectado, interacción con aditivos o adiciones, etc. No es corriente el cemento siderúrgico por su lenta ganancia de resistencias; su mayor ventaja (bajo calor de hidratación) no es aprovechable en el HRFA pues éste se emplea en unidades de poco espesor. Es más corriente el uso de cementos de alta resistencia inicial. La existencia de sulfatos en el terreno limita el contenido en $\mathrm{AC}_{3}$ del cemento que se emplee. Este aspecto puede ser peligroso si el agua en el terreno contiene más de $1.000 \mathrm{mg} / \mathrm{l}$ de $\mathrm{SO}_{4}^{2-}$.

Es conveniente favorecer la docilidad del HRFA incrementando la cantidad de finos mediante la incorporación de adiciones activas en la fabricación del hormigón. Esta opción es delicada, pues exige un riguroso control in situ de la adición; dicho control, por otra parte, es obligado en la fabricación del cemento Portland con adiciones. Así pues, es posible fabricar HRFA con contenidos de cemento entre 450 y $300 \mathrm{~kg} / \mathrm{m}^{3}$. No es recomendable rebasar este límite inferior por su repercusión en la durabilidad y, en todo caso, bajos contenidos de cemento exigirán el empleo de adiciones activas. En el caso de morteros, la demanda de cemento será mayor, no debiendo sobrepasar, en cualquier caso los $500 \mathrm{~kg} / \mathrm{m}^{3}$.

La adición de fibras no impone ninguna especificación adicional al agua de amasado, pero impone un incremento en el volumen de pasta y, por tanto, en el volumen de agua de amasado por $\mathrm{m}^{3}$. Tal incremento puede obtenerse respetando la relación agua efectiva/cemento mediante el aumento de volúmen de conglomerante, ya sea aumentando el contenido de cemento o con el empleo de adiciones activas. Si se emplean adiciones activas debe evaluarse de alguna manera la eficacia de la adición lo que, en términos prácticos, conduce a evaluar la relación agua efectiva/material cementante eficaz.

En la Fig. 1 se aprecia la influencia del contenido de agua y proporción entre los áridos sobre la consistencia. Fijado un contenido de agua (y de pasta, puesto que la relación $\mathrm{a} / \mathrm{c}$ está fija), existe una proporción entre áridos óptima en cuanto a la consistencia. Si falta arena el rozamiento interno del árido grueso y de las fibras interfiere negativamente. Por encima del óptimo de arena su absorción disminuye de nuevo la consistencia. Nótese que el máximo parece no depender del contenido de agua y, por tanto, de pasta. Por supuesto, la consistencia máxima aumenta al crecer el contenido de agua.

\section{2. ÁRIDOS}

En cuanto a su naturaleza mineral, los áridos válidos para un determinado hormigón, lo son también si a éste se añaden fibras. El árido debe ser resistente, no furnace slag cements (type IV ASTM C150, or some of that defined in ASTM C595) are not common to use owing to their slow growth in strength; their most important advantage (low heat hydration) are not beneficial as SFRC is commonly used in thinner sections. It is most common to use high early strength cement (type III ASTM C150). Sulphate content in soil restricts the $\mathrm{AC}_{3}$ content in cement. This can be dangerous if soil water contains more than $1.000 \mathrm{mg} / \mathrm{l}$ of $\mathrm{SO}_{4}^{2}$

Workability of SFRC can be suited through increasing fines content by adding pozzolanic additions during batching. This is a little hard as it is required a rigurous control "in situ" of the addition. In this way, it is possible to make SFRC with cement content between 300 and $450 \mathrm{~kg} / \mathrm{m}^{3}$. It is not recommended to overtake this lower limit because of its influence on durability. In whichever case, lower cement factors will require pozzolanic additions to be added. Cement factors are higher for mortars, but it must not be larger than $500 \mathrm{~kg} / \mathrm{m}^{3}$.

Fibers do not add any more conditions to mixing water than that for normal concrete, but demands some more slurry volume, and large water volume so. This increase in volume of slurry must be done keeping constant the water/cement ratio through increasing cement volume, or by adding pozzolanic additions. If pozzolanic additions are used, efficiency factor of addition must be assesed by any mean. This drives to assess the effective water/effective cement ratio.

Influence of water volume and proportion between fine and coarse aggregate on workability can be seen in Fig. 1. By keeping any water volume (with $w / c$ ratio and fiber dosage constant), one can obtain an optimum coarse to fine aggregate ratio $(G / S)$ for workability. If sand is less than optimum, internal friction between coarse aggregates and fibers will reduce workability. If sand is more than optimum, its absorption will reduce workability again. It's of worth to note the G/S ratio for maximum workability appears not to depend on water content. Obviously, optimum workability increases as water content is more.

\section{AGGREGATES}

With regard to mineral nature of aggregates, those that can be used in any other concrete can be used for the same concrete with fibers. Soundness of aggregates 


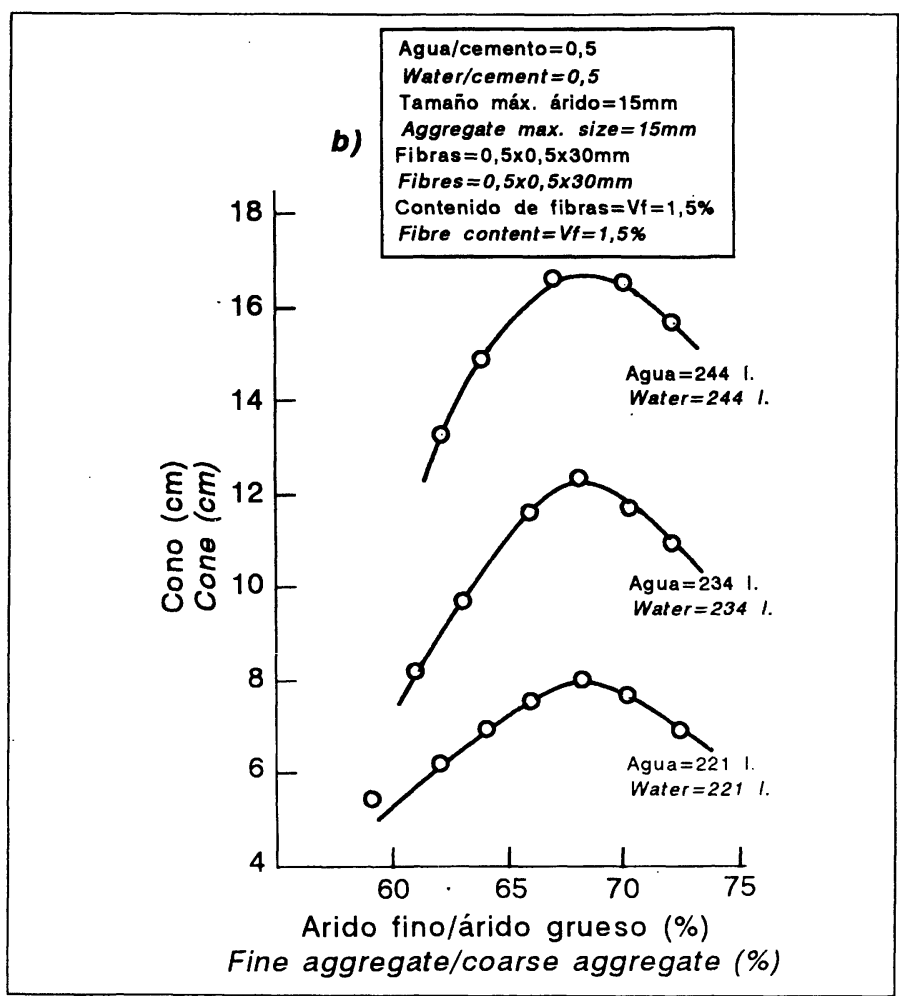

Fig. 1.- Influencia del contenido de agua y la proporción de áridos sobre la consistencia.

Fig. 1.- Influence of water content and proportion of aggregates on consistency.

ligero ni poroso, pues es necesario limitar al máximo su absorción; pero la adición de fibras impone restricciones a determinadas características físicas de los mismos y a su granulometría conjunta.

Pueden emplearse áridos de machaqueo, pero si la mezcla no es satisfactoria, particularmente en cuanto a la docilidad y/o homogeneidad aun empleando granulometrías óptimas, deberá cambiarse a árido rodado, especialmente la arena. Debe considerarse que el empleo de áridos machacados demandará más agua para obtener una determinada docilidad, reduciendo su rozamiento interno.

La adición de fibras exige una mayor cantidad de pasta, puesto que se incrementa la superficie específica que debe rodear ésta; esto exige una mayor proporción de árido fino para evitar la segregación lo que, a su vez, incrementa la absorción y superficie específica del árido conjunto. Por ello, en relación a la arena, es muy importante limitar su contenido en finos, terrones de arcilla y su absorción. Si la absorción de la arena es superior al $1 \%$ de su peso seco y se añade a la masa con una humedad inferior, debe tenerse en cuenta que puede reducir la docilidad, simplemente por absorción durante el amasado. must be in accordance with its use; lightweight and porous aggregates shouldn't be used owing to its high absorption. Fibers addition restricts some physical characteristics of aggregates and its overall gradation.

C'rushed stone can be used, but if mix do not perform well as for workability or homogeneity although good gradation be used, crushed stone should be changed to river sand andior rounded gravel, mainly the first. Crushed aggregates will require more enough water to obtain any preset consistency by reducing their internal friction.

Fibers adding requires much more slurry to envelop specific surface of fibers, so demanding much more sand proportion to avoid segregation. The last one increases water absorption and specific surface itself. Therefore, it's very important to limit its fines content, clay lumps and absorption. If water absorption of sand is larger than $1 \%$ of its dry weight, workability can be reduced for this concept. 


\subsection{Granulometría de los áridos}

La proporción de los áridos entre sí se obtiene, por regla general, del ajuste a una curva o huso granulométrico prefijado. El criterio en hormigón normal suele ser la máxima compacidad dentro de la gama de granulometrías continuas. Las discontinuas pueden dar más compacidad, pero el peligro de segregación es mayor, por lo que son desaconsejables.

En el caso del HRFA se sacrifica, en cierta medida, la compacidad, particularmente si el hormigón va a ser bombeado (2). La esbeltez y proporción de fibras determinan la separación media entre ellas y, por tanto, el tamaño medio o módulo granulométrico del árido conjunto. Su longitud, además, limita superiormente el tamaño máximo del árido, como se ve en el punto 3.

El método de De la Peña suele dar porcentajes de arena altos cuando el tamaño máximo del árido es igual o inferior a $10 \mathrm{~mm}$. El resultado puede ser correcto para HRFA si la arena no es muy gruesa. Si su módulo de finura es superior a 2,70 el contenido de arena puede ser alto.

La granulometría para un HRFA se encuentra por encima de la "ideal" correspondiente a un hormigón normal colocado en las mismas condiciones. Se incrementa el volumen de pasta y mortero y debe reducirse el tamaño máximo, bien para evitar erizos, bien para evitar la segregación. La norma DIN 1045 propone 2 husos granulométricos, definidos por 3 curvas para granulometrías conjuntas de tamaño máximo $8 \mathrm{~mm}$. Estas líneas se incluyen en la Tabla 1 . Por su parte, la Asociación Francesa del Hormigón (5) recomienda los husos granulométricos recogidos en la Tabla 2 para hormigón proyectado.

En un plan de ensayos hemos empleado el método de Faury, ACI 211 y De la Peña para el diseño de un

\subsection{Size gradation of aggregates}

Fine to coarse aggregates ratio are normally obtained through adjusting the overall gradation to some gradation curve or envelope. Criterion for plain concrete is often to match the minimum void volume within smooth gradation curves to be filled with water and cement. Discontinous grades are able to have less void volume, but it's more likely segregation to occur.

In SFRC, design mixes usually haven 't got the minimum void volume, especially if concrete is going to be pump (2). Aspect ratio of fibers and fibers ratio determine average space between them and, therefore, average size or granulometric modulus for the mix of aggregates. Moreover, length of fibers gives us an upper limit for maximum size of aggregates, as can be seen in 3.

De la Peña's method (often used in Spain) normally gives high percentages of sand when maximum size of aggregate is equal or less than $10 \mathrm{~mm}$. It can be right for SFRC if sand is not too coarse. If fineness modulus is higher than 2.70, sand content can be too high.

Size gradation for SFRC are over that for plain concrete placed in the same conditions. Slurry and mortar volume are increased and maximum size of aggregate must be reduced, either to avoid formation of fiber balls, or to avoid segregation. DIN 1045 standard proposes two gradation envelopes, defined by three gradation.curves, for maximum size of $8 \mathrm{~mm}$. This curves are included in Table 1. On the other hand, the French Concrete Association (5) recommends gradation envelopes included in Table 2 for shotcrete.

In certain work we have used Faury's method (created in French, and known in Spain), ACI's method and De la

TABLA 1 ( TABLE 1)

Husos granulométricos para $\mathrm{D}_{\operatorname{mix}}=8 \mathrm{~mm}$. Tanto por ciento en peso que pasa por cada tamiz (Gradation envelopes for max. size $=8 \mathrm{~mm}$. Percent passing each sieve)

\begin{tabular}{||c|c|c|c|c|c||}
\hline Tamiz (Sieve) (mm) & 8 & 4 & 2 & 1 & 0,25 \\
\hline Curva (Curve) A & 100 & 61 & 36 & 21 & 5 \\
\hline Curva (Curve) B & 100 & 74 & 57 & 42 & 11 \\
\hline Curva (Curve) C & 100 & 85 & 71 & 57 & 21 \\
\hline $\begin{array}{c}\text { Curva (Curve) D } \\
\text { discontinuas } \\
\text { (dicontinuous) }\end{array}$ & 100 & 30 & 30 & 30 & 5 \\
\hline
\end{tabular}


Husos granulométricos de la Asociation Française du Béton para hormigón proyectado

(Gradation envelopes from Association Française du béton for shotcrete)

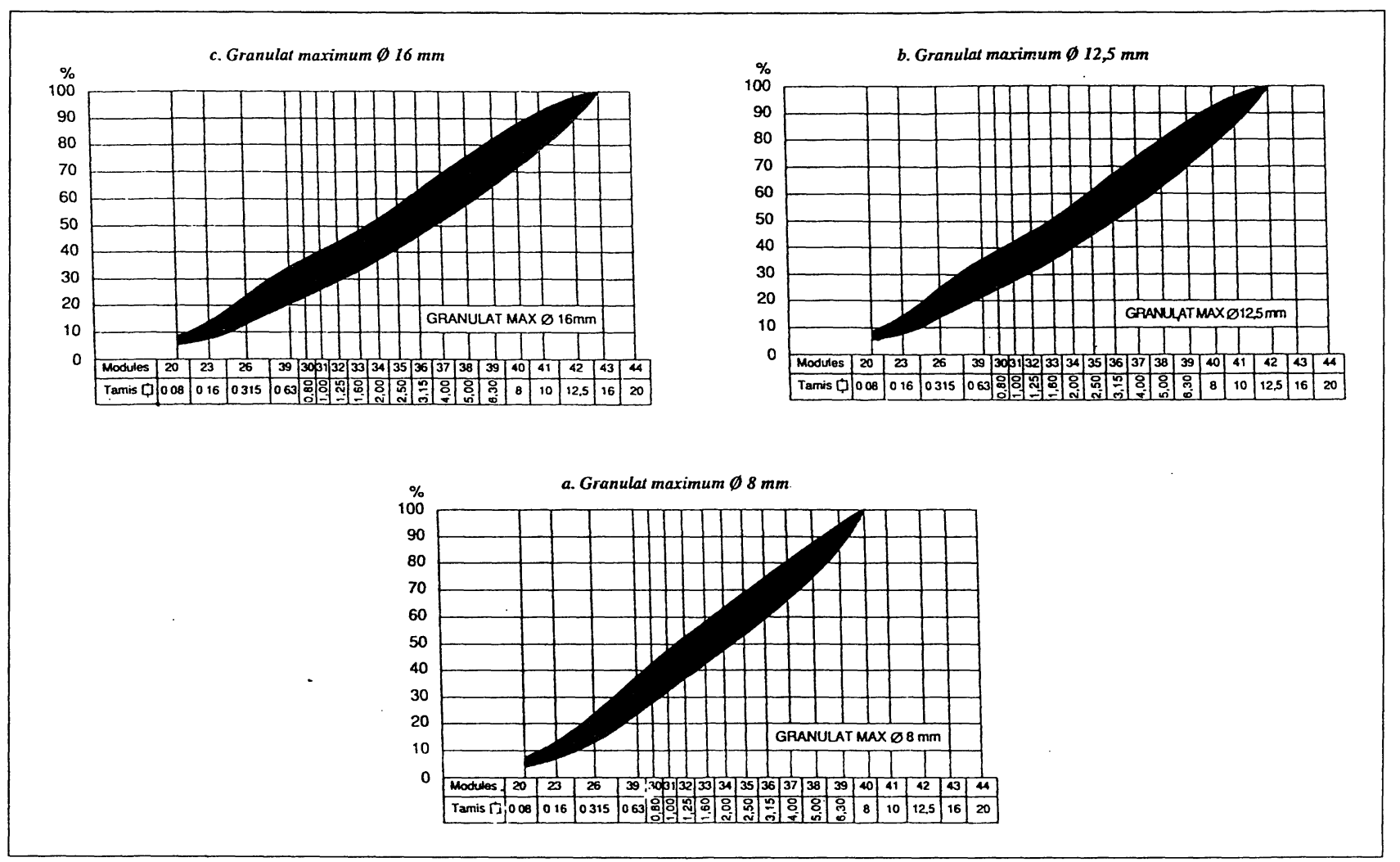

HRFA, cuyas cuantias de fibra eran 40,80 y $120 \mathrm{~kg} / \mathrm{m}^{3}$. Se pretendía alcanzar una resistencia característica a compresión del hormigón sin fibras de $40 \mathrm{Mpa}$. La dosificación debía adaptarse a la adición elevada de fibras que se pretendía, pero ser igualmente aceptable para un hormigón convencional, exigiéndose un cono de $6 \mathrm{~cm}$ con $40 \mathrm{~kg} / \mathrm{m}^{3}$ de fibras. El proyecto (10) consistía en la fabricación, en el Laboratorio de Materiales de Construcción de la E.T.S. de Ingenieros de Caminos, C. y P. de Madrid, de una gran serie de placas de HRFA con dimensiones oscilando entre $60 \times 60$ y $50 \times 50 \mathrm{~cm}$, con espesores entre 6 y $20 \mathrm{~cm}$. Dado el gran número de placas a realizar, éstas debían desalojarse del Laboratorio en un período corto de tiempo, lo que nos llevó a usar un cemento I-45A.

El tamaño máximo escogido para el árido grueso machacado fue $10 \mathrm{~mm}$, siendo la arena rodada, con un módulo de finura de 2,68 . Tanto la arena como la gravilla estaban secas. Las fibras empleadas tenían los extremos conformados y encoladas, fabricadas por trefilado (tipo I de la norma UNE 83500), su longitud era de $50 \mathrm{~mm}$ y $0,5 \mathrm{~mm}$ de diámetro, con una esbeltez 100. Estas fibras son las más difíciles de mezclar. La dosificación definitiva por $\mathrm{m}^{3}$ fue:
Peña's method to design a SFRC with fibers quantities of 40,80 y $120 \mathrm{~kg} / \mathrm{m}^{3}$ of concrete. It was intended to obtain a characteristic strength of $40 \mathrm{Mpa}$. Mix design had to admit the large fibers dosage into, but being acceptable as plain concrete, and requiring $6 \mathrm{~cm}$ slump with $40 \mathrm{~kg} / \mathrm{m}^{3}$ of fibers. The project (10) consisted on making a very large serie of SFR( plates in Building Materials laboratory of the E.T.S. de Ingenieros de Caminos, C. y P. de Madrid. SFRC' plates had $60 \times 60$ and $50 \times 50 \mathrm{~cm}$ in size, with a thickness varying between 6 and $20 \mathrm{~cm}$. As the number of plates was very large and they had to be brought out of laboratory soon, we pick up an early high strength cement with a strength of $45 \mathrm{Mpa}$ (type I-45A according to Spanish standard).

Maximum size of aggregate was $10 \mathrm{~mm}$, with fineness modulus of sand equal to 2.68. Both sand and coarse aggregate were dry. Cold drawn steel (type I in accordance with UNE 83500) hooked end fibers were used. Fibers were glued into bundles to do mixing easier. The length of fibers were $50 \mathrm{~mm}$ and their diameter were $0.5 \mathrm{~mm}$, so having an aspect ratio of 100. This fibers are the most difficult to mix. Final mix design was: 


\begin{tabular}{||c|c|c|c|c||}
\hline $\begin{array}{c}\text { Cemento I-45A } \\
\text { (Cement I-45A) }\end{array}$ & $\begin{array}{c}\text { Arena } \\
\text { (Sand) }\end{array}$ & $\begin{array}{c}\text { Gravilla } \\
\text { (Fine gravel) }\end{array}$ & $\begin{array}{c}\text { Agua } \\
\text { (Water) }\end{array}$ & $\begin{array}{c}\text { Superplastif. } \\
\text { (Superp/astic.) }\end{array}$ \\
\hline $400 \mathrm{~kg}$ & $980 \mathrm{~kg}$ & $851 \mathrm{~kg}$ & 1771 & $5,5 \mathrm{~kg}$ \\
\hline
\end{tabular}

Dado que los áridos tenían una absorción importante, la mezcla anterior pudo albergar hasta $120 \mathrm{~kg} / \mathrm{m}^{3}$ de fibras, modificando el proceso de amasado. Se mezclaron en primer lugar el cemento y la arena. A continuación se añadía, aproximadamente, la mitad o dos tercios del agua (sin mezclar con el superplastificante). Después se añadía la mitad de la gravilla y el resto del agua con el superplastificante mezclado. Finalmente se añadían las fibras y el resto de la gravilla con el tiempo justo de homogeneización. Las proporciones de cada componente y los tiempos que dura cada fase dependen de los medios de amasado y del volumen del mismo, así como la cuantía de fibras.

Los ensayos de resistencia mecánica que se realizaron tenian como objeto garantizar la resistencia especificada (Tabla 3). Aunque estos ensayos no eran el objetivo fundamental del trabajo, se pudo observar un aumento significativo de la dispersión (desviación típica y coeficiente de variación) de los resultados conforme aumenta el contenido de fibras. Este aumento llegaba a anular la mejora en la resistencia media que se produce aumentando el contenido de fibras.
Since aggregates had a very important absorption, the mix was able to contain $120 \mathrm{~kg} / \mathrm{m}^{3}$ of fibers only through modifying the mix procedure. The first step was to premix sand and cement. The next step was to add approximately a half or two thirds of water (without superplasticizer). Then, a half of coarse aggregate and remaining water with all of the superplasticizer were mixed. Finally, remaining gravel and fibers were added just to disperse them into the batch. Proportions of each component at each step and time depends on batching tools and its volume, as well as fibers dosage.

Compressive strength tests made are intended to assure the specified characteristic strength (Table 3).

Although this test are not the main purpose of the work, a significant increase in scatter (both in typical deviation and variation coefficient) was able to be observed as fibers dosage raised. This increasing scatter reached to offset the (minimum) improvement in average strength caused by fibers.

TABLA 3 (TABLE 3)

Resistencia a compresión de HRFA (28 dias de edad)

(Compressive strength of SFRC at 28 days)

\begin{tabular}{|c|c|c|c|c|c||}
\hline $\begin{array}{c}\text { Cuantía } \\
\text { (Quantity) } \\
\left(\mathrm{kg} / \mathrm{m}^{3}\right)\end{array}$ & $\begin{array}{c}\mathrm{n}^{\circ} \mathrm{de} \\
\text { datos } \\
\text { (data) }\end{array}$ & $\begin{array}{c}\text { Media muestral } \\
\text { (Sample } \\
\text { average) } \\
\text { (Mpa) }\end{array}$ & $\begin{array}{c}\text { D. típica } \\
\text { muestral } \\
\text { (D. typical } \\
\text { sample) } \\
\text { (Mpa) }\end{array}$ & $\begin{array}{c}\text { Coef. de } \\
\text { variación } \\
\text { (Variation } \\
\text { rate) } \\
\text { (\%) }\end{array}$ & $\begin{array}{c}\text { Resistencia } \\
\text { caracteristica } \\
\text { (Characteristic } \\
\text { resistance) } \\
\text { (Mpa) }\end{array}$ \\
\hline 0 & 6 & 44,5 & 1,51 & 3,4 & 42,0 \\
\hline 40 & 6 & 46,1 & 1,77 & 3,8 & 43,2 \\
\hline 80 & 6 & 49,5 & 2,17 & 4,4 & 45,9 \\
\hline 120 & 6 & 50,7 & 3,20 & 6,3 & 45,4 \\
\hline
\end{tabular}

\section{VOLUMEN RELATIVO DE FIBRAS}

La longitud y esbeltez de las fibras influyen en la dosificación del HRFA. Ambas características determinan el tamaño medio y máximo del árido conjunto empleado en el hormigón.

Puede demostrarse (8) que en una distribución uniforme de las fibras en $2-\mathrm{D}$, el $\mathrm{n}^{\circ}$ de fibras medio por

\section{VOLUME OF FIBERS}

Length and aspect ratio of fibers affect mix design for SFRC. Both the length and aspect ratio point out the averaged and maximum size of the aggregate used in SFRC.

It has been demonstrated (8) that the average number of fibers per surface unit crossing any plane with any 
unidad de superficie que atraviesan un plano cualquiera con cualquier inclinación es: $n=2 v_{f} / \pi A_{1 f}$; y en el caso 3-D: $n=v_{f} / 2 A_{1 f}$, donde $A_{1 f}$ es la sección transversal de una fibra. La separación media entre las fibras "s" en el plano se puede calcular aproximadamente por: $s=1 / n^{1 / 2}$, aunque variará con la disposición relativa que adopten las fibras en el plano de corte. Esta separación media entre las fibras está relacionada con el tamaño medio de los granos de árido que pueden introducirse en la mezcla sin que afecte a la distribución aleatoria de las fibras. La separación media "s" sería el máximo tamaño de grano que se podría colocar entre fibras, si éstas estuviesen todas alineadas y perpendiculares al plano de corte considerado. La libertad de posición y orientación relativa entre ellas, así como la variabilidad en la separación media permite que el tamaño máximo admisible sea del orden del doble de la separación media "s" entre fibras. En la Tabla 4 se indica el tamaño máximo admisible con este criterio, para varios casos usuales de fibra recta. tilt through an uniform distribution of fibers in 2-D can be obtained as: $n=2 v_{f} / \pi A_{1 f}$; and for 3-D it is: $n=v_{f}, / 2 A_{1 f}$ where $A_{1 f}$ is the cross section of one fiber. Average separation between fibers " $s$ " can be calculated approximately by $s=1 / n^{1 / 2}$, although it will vary with relative arrangement between fibers on the crossing section. This average separation are related with average size of aggregates which can be introduced in any mix without affecting the random distribution of fibers. The average separation " $s$ " would be the maximum size of aggregates that can be introduced between fibers if all fibers were at right angle with crossing section considered. The freedom of position and arrangement between fibers, as well as the scatter in average separation " $s$ " between them, allow for maximum size of aggregate to be two times the average separation " $s$ " between fibers approximately. Table 4 shows the maximum size calculated in this way, for some standard straight fibers.

TABLA 4 (TABLE 4)

Tamaño máximo (mm) admisible para varios casos usuales

(Maximum size for usual cases)

\begin{tabular}{|c|c|c|c|c||}
\hline \multirow{2}{*}{$\begin{array}{c}\text { Volumen de fibras } \\
\text { Fibres volume) } \\
(\%)\end{array}$} & \multicolumn{4}{|c|}{ Diámetro de fibras (Fibres diameter) (mm) } \\
\cline { 2 - 5 } & 0,3 & 0,5 & 0,8 & 1,0 \\
\hline 0,25 & 15 & 25 & 40 & 50 \\
\hline 0,50 & 10 & 18 & 28 & 35 \\
\hline 1,00 & 7,5 & 12,5 & 20 & 25 \\
\hline 1,50 & 6 & 10 & 16 & 20 \\
\hline
\end{tabular}

Obsérvese que la condición anterior no depende directamente de la longitud de las fibras, lo que resulta lógico, ya que si la longitud de las fibras es, p. ej., el doble, el número de fibras por $\mathrm{m}^{3}$ deberá reducirse a la mitad puesto que mantenemos el volumen de fibras por $\mathrm{m}^{3}$ constante. Pero esto es cierto solamente en el caso ideal (del que se derivan las fórmulas) de fibras alineadas y perpendiculares al plano de corte. En la práctica, las fibras más cortas gozan de más libertad para situarse en la masa, principalmente cerca de paredes. En cambio, las fórmulas son muy críticas respecto al diámetro de la fibra y, por tanto, del proceso de trefilado.

Un eficaz anclaje de las fibras en la matriz determina que la longitud de éstas sea mayor que el tamaño máximo de árido. Por este motivo es aconsejable que el tamaño máximo no sea mayor que los $2 / 3$, y mejor menor de $1 / 2$ de la longitud de la fibra.
It's of worth standing out that equation above do not depend on length of fibers directly. It's normal since if the length of fibers is, viz. two times larger, the number of fibers per cubic meter will be only one half, as we keep the fiber volume per cubic meter constant. However, this is right on the ideal case (through which the formulae are obtained) of fibers normal to crossing section only. In practice, shorter fibers are more free to place themselves in the mix, mainly close to walls. On the other hand, formulae depend very much on fiber diameter and cold drawing process so.

Fibers length must be larger than maximum size of aggregate for an efficient anchorage. For this reason maximum size of aggregate wouldn't be larger than two thirds, and better less than one half of fiber length. 
Tatnall (12) propone el siguiente criterio para determinar el contenido máximo o crítico de fibras:
Tatnall (12) proposes the next criteria to determine the maximum or critical volume of fibers:

$$
v_{\mathrm{f}, \max }=0,5933 \mathrm{a}\left[\frac{\mathrm{F}(\%)}{100} \cdot 1,6+\frac{\mathrm{G}(\%)}{100} \cdot \mathrm{b}\right]\left(\mathrm{kg} / \mathrm{m}^{3}\right)
$$

siendo:

$\mathrm{F}=$ porcentaje de arena en peso respecto al total de árido

$\mathrm{G}=$ porcentaje de árido grueso en peso respecto al total de árido $(100-\mathrm{F})$

a = parámetro que depende de la esbeltez de las fibras (ver Tabla 5 )

$\mathrm{b}=$ parámetro que depende del tamaño máximo del árido (Tabla 5) where:

$F=$ percentage of sand in weight with regard to total weight of aggregate

$G=$ percentage of coarse aggregate in weight with regard to total weight of aggregate (100 - F)

$a=$ Variable depending upon aspect ratio of fibers (See Table 5)

$b=$ Variable depending upon maximum size of aggregate (Table 5)

TABLA 5 (TABLE 5)

Parámetros "a" y "b" en función de la esbeltez de las fibras y huso granulométrico

(Parameters " $a$ " $y$ " $b$ " for aspect ratio and gradation)

\begin{tabular}{|c|c|c|c||}
\hline $\begin{array}{c}\text { Esbeltez } \\
\text { (Slenderness) }\end{array}$ & $\mathrm{a}$ & $\begin{array}{c}\text { Granulometría } \\
\text { (Gradation) } \\
\text { ASTM N }\end{array}$ & $\mathrm{b}$ \\
\hline 60 & 220 & 6 & $-0,08$ \\
\hline 75 & 176 & 67 & 0,06 \\
\hline 100 & 132 & 68 & 0,12 \\
\hline-- & $-\cdots$ & 7 & 0,23 \\
\hline-- & -- & 78 & 0,25 \\
\hline-- & --- & 8 & 0,45 \\
\hline
\end{tabular}

Una propuesta interesante es la de Moens, que limita el producto $v_{f} \cdot 1 / d$ en función del contenido de cada fracción de árido:
Another interesting proposal is done by Moens, who limits the product $v_{f} \cdot 1 / d$ regarding the proportion of each size of aggregate:

$$
v_{\mathrm{f}} \frac{\mathrm{l}}{\mathrm{d}} \leq \mathrm{C}_{\mathrm{m}}
$$

con $\mathrm{C}_{\mathrm{m}}=\Sigma \mathrm{P}_{\mathrm{gn}} \cdot \mathrm{C}_{\mathrm{gn}}$, donde:

$P_{g n}=$ proporción de cada fracción de árido (ver Tabla 6)

$\mathrm{C}_{\mathrm{gn}}=$ coeficiente que depende de la fracción de árido (ver Tabla 6 ).

En la Fig. 2 se observa la influencia del volumen de fibras sobre la consistencia. Un aumento en el volumen de fibras precisa un incremento en el volumen de pasta para obtener la misma consistencia (pero esto sólo no es suficiente, hay que incrementar la proporción de árido fino). Como se ve, la falta de arena permite que la where $C_{m}=\Sigma P_{g n} \cdot C_{g n}$ and:

$P_{g n}=$ proportion of each size of aggregate (see Table 6).

$C_{g n}=$ coefficient depending upon size of aggregate (Table 6).

In Fig. 2 influence of fibers volume on consistency can be observed. An increase in fibers volume needs for an increase in slurry to keep the same consistency (but proportion of fine aggregate must also be increased). As can be seen, if proportion of sand is not sufficient, stiffness brought about by fibers and internal friction 
TABLA 6 (TABLE 6)

Valores de $\mathrm{C}_{\mathrm{gn}}$ (Values for $\mathrm{C}_{\mathrm{gn}}$ )

\begin{tabular}{||c|c|c|c||}
\hline $\begin{array}{c}\text { Tamaño del árido } \\
\text { (Aggregate size) } \\
(\mathrm{mm})\end{array}$ & $\mathrm{C}_{8}$ mín & $\mathrm{C}_{8}$ máx. & $\mathrm{C}_{8}$ med. \\
\hline $0-2$ & 1,70 & 2,00 & 1,85 \\
\hline $2-4$ & 0,95 & 1,12 & 1,03 \\
\hline $2-7$ & 0,66 & 0,91 & 0,78 \\
\hline $4-7$ & 0,54 & 0,69 & 0,62 \\
\hline $7-14$ & 0,10 & 0,22 & 0,16 \\
\hline $7-20$ & 0,00 & 0,13 & 0,07 \\
\hline
\end{tabular}

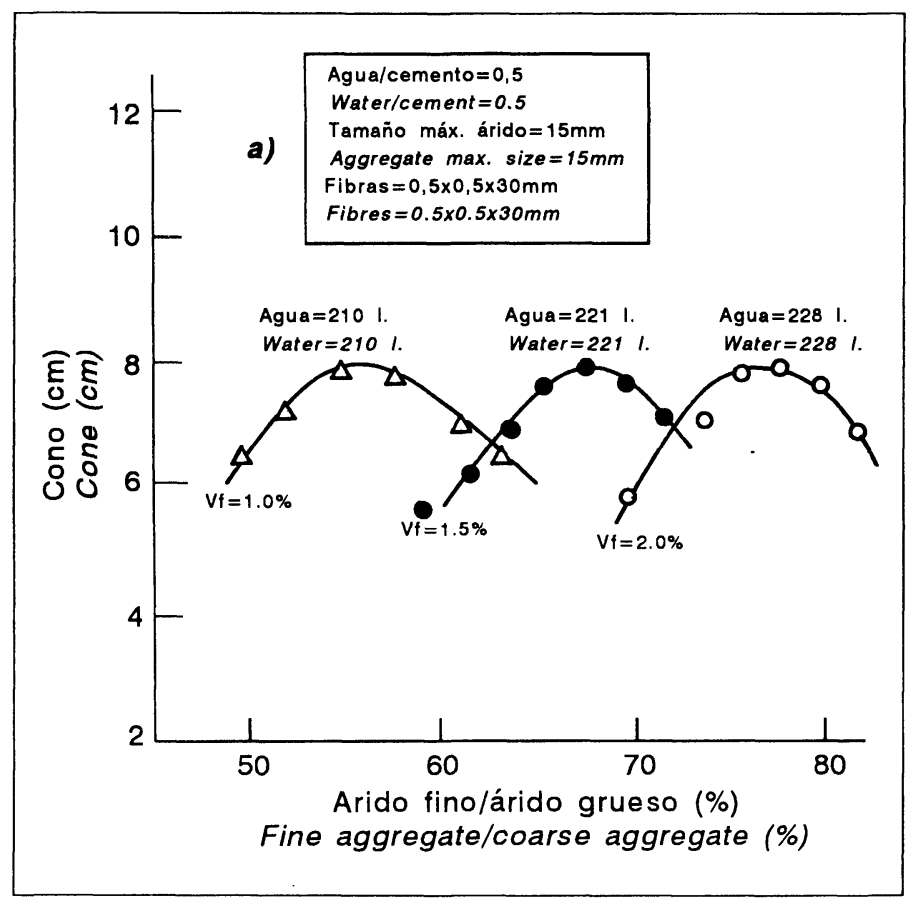

Fig. 2.- Influencia de la cuantía de tibras sobre la consistencia.

Fig. 2.- Influence of fibers volume on consistency.

rigìdez que aportan las fibras y el rozamiento del árido grueso baje la consistencia, incluso por debajo de la de una mezcla con menos agua. Los datos numéricos del ensayo no deben tomarse como referencia absoluta, pero sí indican que el árido fino debe encontrarse en una proporción próxima o algo superior al $50 \%$ del árido total.

La cuantía, longitud, esbeltez y geometria de las fibras también influyen en las propiedades mecánicas del HRFA. La eficacia relativa de fibras heterogéneas puede medirse mediante su carta de identidad $(9,14)$, que consiste en un gráfico $X-Y$, en el que en abscisas se coloca la cuantía de fibras y en ordenadas las variables between coarse aggregates will reduce the workability, even below that for mixes with less water. Data from trial mixes mustn 't be taken as an absolute reference. but these data point out proportion of sand could be around $50 \%$ of total weight of aggregate.

Quantity, length, aspect ratio and geometry of fibers also affect mechanical properties of SFRC. Lfficiency of any type of fiber can be measured by identity charts $(9,14)$ which are an X-Y graphs where, in abscissa, fibers quantity is placed, and the ordinate axis contains the control variable. This variable is measured by 
de control, que se miden con la normativa habitual $(3,4)$ o mediante ensayo de punzonado en placa $(11)$.

\section{ADITIVOS}

Los aditivos que se emplean con mayor frecuencia en el HRFA son los reductores de agua y superplastificantes, y los acelerantes. Estos últimos se emplean en la técnica del HRFA proyectado.

El aumento del volumen de agua para incrementar la docilidad es escasamente provechosa. Produce, evidentemente, una reducción en las resistencias y en la durabilidad del material, por su mayor porosidad; y es poco útil por el efecto rigidizador de las fibras. Resulta más conveniente actuar sobre la viscosidad de la pasta mediante reductores de agua y superplastificantes.

Los aditivos no permiten aumentar indiscriminadamente el contenido de fibras. El aumento en la cuantía de fibras conduce a una disminución de la separación media entre ellas y a su apelotonamiento, y esto es independiente del uso de aditivos. Puede decirse que existe un límite máximo en el porcentaje de fibras de un determinado tipo que pueden añadirse a un hormigón con una granulometría dada y un proceso de fabricación determinado.

Si diseñamos un hormigón con la dosificación máxima de fibras, los aditivos nos permitirían aumentar su docilidad, pero no nos permiten "canjear" docilidad por cuantía de fibras puesto que estamos en el límite de contenido máximo de éstas. Esto sólo es posible si partimos de un contenido de fibras inferior al máximo.

Suponiendo que se mantiene el contenido de fibras y que la granulometría es correcta, la falta de trabajabilidad puede deberse: a) a un escaso volumen de pasta, o b) a una excesiva viscosidad de ésta (baja relación agua libre/cemento), además del efecto rigidizador de las fibras. La causa a) es debida a falta de agua y cemento por $\mathrm{m}^{3}$, consecuencia de una mala dosificación y debe corregirse "a priori". La causa b) es más compleja, pues influye el tipo de cemento y la absorción de los áridos disponibles, pero en ella es donde los aditivos son una solución, pudiendo "canjearse" relación agua libre/cemento menor por mayor dosis de aditivo, a igual docilidad, pero mejorando la resistencia y durabilidad del hormigón.

Es conocido que debe estudiarse la compatibilidad cemento-aditivo plastificante para conseguir la combinación y dosis óptima. Una desviación del "óptimo" se traduce en pérdida acelerada de docilidad, segregación o exudación de la masa. No pueden darse normas generales, porque cementos clasificados en la misma categoría, según la normativa existente, tienen current standards $(3,4)$ or by plate punching trials (ll).

\section{ADMIXTURES}

Admixtures as water-reducing agents, superplasticizers and accelerating agents are often used in SFRC. The last are mainly used in shotcrete.

Rising up volume of water to reach a better workability are not very advantegeous. This reduces both mechanical strength and strength against environment (durability) because it produces larger porosity, and it is not very useful against stiffening effect of fibers. Adding water-reducing agents or superplasticizers to minimize the viscosity of slurry are more advisable.

Admixtures don't allow to add any volume of fibers to mix. As quantity of fibers is increased average separation between them is reduced, so increasing the risk of "balling", and it doesn 't depend on admixtures. It can be said that a maximum or critical volume of fibers exists for any kind of concrete regarding to size gradation and mixing process.

If we design some concrete with the critical volume of fibers, admixtures would allow us to increase workability, but they will not allow us to "change" workability with volume of fibers, because it is just on the maximum. It's only possible if volume of fibers were less than critical volume.

Assuming fibers quantity is constant and size gradation is right, a poor workability can be due to: a) a little slurry volume, or b) a slurry much too viscous (lower water/cement ratio), besides the stiffening effect of fibers. (ase a) is due to lower water and cement volume per $\mathrm{m}^{3}$ as a consequence of a bad mix design and it must be corrected just before trial mixes. Case b) is more complex as both cement type and absorption of aggregates have influence on it. In the last case, admixtures are a solution and allow less water/cement ratio and larger admixture dosage to change with the same workability and better strength and durability.

Compatibility between cements and plasticizers must be studied to know both optimum combination and dosage of plasticizer. If combination or dosage of plasticizer is not adequate, there will be a fast loss of workability or some risk of bleeding or segregation. (ieneral rules cannot be done because of some cements within the same type according to standards have 
diferente comportamiento frente a un mismo aditivo, y viceversa. Aunque existen estudios de compatibilidad cemento-aditivos, estos se refieren a cementos locales como es natural- y el aditivo es un compuesto químico puro o es un producto comercial, el cual es siempre una mezcla de varios compuestos activos. Debe tenerse en cuenta, en cualquier caso, el agua libre aportada por los aditivos y el contenido en $\mathrm{AC}_{3}$ del cemento en cuestión.

Se puede decir lo mismo de los acelerantes en cuanto a su compatibilidad con el conglomerante. También debe conocerse su efecto sobre el tiempo de fraguado, resistencia inicial y pérdida de resistencia a largo plazo, que puede ser muy acusada; además del peligro de corrosión en las armaduras, aunque existen ciertos acelerantes (tiocianato de sodio, nitrito de calcio) que no tienen este riesgo.

Si el aditivo se emplea en exceso para mejorar la docilidad manteniendo la relación agua/cemento, de análoga manera al efecto de una excesiva cantidad de agua, la pasta se fluidifica excesivamente, separándose o exudando del conjunto de áridos y fibras. Si se emplea para reducir el volumen de agua manteniendo el peso de cemento constante, segregará por falta de pasta, aunque se mantuviera la fluidez de la misma.

\section{ADICIONES ACTIVAS}

Las adiciones habituales al cemento son las puzolanas, las cenizas volantes, las escorias siderúrgicas, el filler calizo y el humo de sílice.

La característica común a todos ellos es un peso específico menor que el de cemento; por ello, una sustitución por igual peso de éste conduce a un incremento en el volumen de finos y, por tanto, en el volumen de pasta, lo que permite acomodar las fibras en la mezcla sin necesidad de aumentar exageradamente el contenido de cemento.

La superficie específica, medida por el permeabilimetro de Blaine, de estas adiciones es semejante a la del cemento; a excepción del humo de sílice que tiene una finura muy superior y la escoria siderúrgica, que se muele a una finura ligeramente superior para compensar su lento endurecimiento.

La demanda de agua de la adición depende de su superficie específica, entre otros factores particulares de cada adición. El humo de sílice, que alcanza hasta $20.000 \mathrm{~cm}^{2} / \mathrm{gr}$ (medida por adsorción de nitrógeno), adsorbe agua en proporción muy importante a su peso. La adsorción de agua del humo de sílice obliga al uso de reductores de agua y superfluidificantes. El humo de sílice colabora en la ganancia de resistencia si se añade un mínimo de 8 hasta $15 \%$ en peso de cemento; por different performance with the same admixture, and vice versa. Although there are some studies on compatibility of cement-admixtures, these are refered to local cements -which is normal-, and admixtures can be a pure chemical substance or a trade mark, which is ever a mix of various active components. It must take into account, in whichever case, the free water brought by admixtures and $\mathrm{AC}_{3}$ content in cement.

The same can be said about accelerating admixtures on its compatibility with cement. Its effect on setting time, early strength and loss of strength at long ageswhich can be very large- must be known; as well as the risk as for corrosion from steel, although some admixtures already have not this problem, such as sodium thyocyanate or calcium nitrite.

If admixture were used in excess to improve workability maintaining water/cement ratio, like for an excess of water, the slurry would gain too much fluidity, causing slurry to bleed. If admixture were used in excess to reduce volume of water with weight of cement constant, segregation could occur for a lack of volume of slurry, although its fluidity remained the same.

\section{ACTIVE ADDITIONS}

( ustomary additions to concrete are pozzolans, fly ashes. blast furnace slags, calcium filler and microsilica.

All of those has a bulk specific gravity less than that for cement; therefore, changing any weight of cement with the same weight of addition leads to a larger volume of fines, so increasing the volume of slurry and, in this way, a larger volume of fibers can be accomodated without any increase in volume of cement.

Blaine specific surface of these additions are similar to that of cement; but microsilica has much too larger specific surface, and blast furnace slag has a specific surface a little greater than that of cement to compensate its slower hardening.

Water demand of addition depends on its specific surface very much, as well as on particular variables of each addition. Microsilica, with a specific surface close to $20.000 \mathrm{~cm}^{2} / \mathrm{gr}$ (by nitrogen adsorption). adsorbs much water in proportion to its weight. This adsorption of microsilica leads to use water-reducing admixtures and superplaticizers. Microsilica contributes to strength gain if added in proportion greater than 8 up to $15 \%$ to weight of cement; if added 
debajo del $8 \%$ puede añadirse tambien para aumentar la cohesión de la mezcla, cerrar poros, e impedir el lavado de la misma bajo el efecto de corrientes de agua.

La demanda de agua de las cenizas volantes depende del porcentaje de carbono no quemado, es decir, de su pérdida por calcinación. Es corriente que la finura de una ceniza se incremente si tiene un porcentaje de inquemados elevado (por encima del $5 \%$ ), pues el tamaño medio de los granos de carbón pulverizado empleado en las centrales es inferior al de las cenizas resultantes de la combustión. Esto sugiere que los granos de carbón no quemado se aglomeran en la combustión; este comportamiento es típico de las hullas grasas y semigrasas en el proceso de coquización o destilación seca del carbón no quemado en el interior del horno. Este proceso se produce en mayor o menor grado, dependiendo de la temperatura del horno. La elevada adsorción del carbón no quemado influye negativamente en la efectividad de los aditivos mezclados con agua que se empleen en el hormigón.

Las adiciones activas forman parte del conglomerante total del hormigón. Como este conglomerante se considera en la dosificación a través de la relación $(\mathrm{a} / \mathrm{c})$ y del contenido de cemento más adiciones, debe valorarse la efectividad de las mismas en relación a aquellas características del hormigón que dependen de la relación $(\mathrm{a} / \mathrm{c})$ y del contenido de cemento. Dicha valoración se realiza a través del concepto de coeficiente de eficacia. La influencia de las fibras en dicho coeficiente de eficacia es sólo indirecta, a través del cambio en la dosificación y en las características mencionadas arriba.

La cantidad de adición activa viene definida por su proporción, en peso, con respecto al contenido de cemento. Para el caso de cenizas volantes y puzolanas, dicha proporción puede tomarse entre el 15 y el $35 \%$ del peso de cemento. En términos de comparación, se obtienen dosificaciones diferentes si dicho porcentaje: a) se añade simplemente a una dosificación por $\mathrm{m}^{3} \mathrm{de}$ partida; b) se sustituye volumen de cemento y/o arena por volumen de adición respecto a la dosificación de referencia.

\section{HORMIGÓN Y MORTERO PROYECTADO}

En general, las exigencias que la adición de fibras de acero imponen a la dosificación favorecen la aptitud del hormigón o mortero con fibras para ser bombeado y proyectado.

El conducto de transporte de la mezcla, ya sea ésta seca o húmeda, debe ser más rígido de lo habitual en hormigón convencional, evitando los codos en lo in proportion lesser than $8 \%$ to weight of cement increases cohesiveness, renders concrete to have less porousity, and avoids concrete to wash under water streams.

Water demand of fly ashes also depend on their unburned carbon percentages, that is on their calcination loss. It 's normal fineness of any fly ash to increase when unburned percentage is big (greater than $5 \%$ ), but average size of ground carbon used in thermal power plants are usually lesser than that of fly ashes. It suggests unburned carbon particles agglomerate during combustion, which is normal to occur for bituminous and subbituminous coals during coking of unburned carbon particles within the furnace. Coking ever occurs in some degree depending upon temperature inside the furnace. The great adsorption of unburned carbon has a negative influence on efficiency of admixtures added to mixed water.

Active additions are a part of cementitious materials of concrete. Therefore its influence on properties depending upon water/cement ratio and cement content must be assesed because water/cement ratio and cement content are the mix design variables. Assesment is done through efficiency coefficient factor. Influence of fibers on this coefficient are indirect only, through changing mix design concept and properties mentioned above.

Weight per $m^{3}$ of addition are usually defined from weight per $\mathrm{m}^{3}$ of cement. Weight of fly ashes and pozzolans are normally between 15 and $35 \%$ of weight of cement. Mix proportions can be obtained either: a) simply adding weight of pozzolans to some reference mix proportion without pozzolans or b) by changing cement and/or sand volume from some reference mix to pozzolan volume.

\section{SHOTCRETE}

Requirements for fibers to mix proportion improve performance of SFRC to be pumped and shooted.

Conveyor duct both in dry and wet mix process would be stiffer than normal for plain concrete, avoiding knees as far as possible. Diameter of conveyor duct 
posible. El diámetro del conducto limita el tamaño máximo del árido y la longitud de las fibras que deben circular por él. Una regla comúnmente aceptada es que la longitud de las fibras debe ser menor o igual que la mitad del diámetro del conducto. Así, las fibras para hormigón o mortero proyectado suelen ser de menor longitud que las normales. Un valor recomendable son $30 \mathrm{~mm}$. La esbeltez óptima de la fibra también es menor por el fenómeno del rebote; por lo que las fibras suelen tener, también, un diámetro del orden de 0,8 ó $1 \mathrm{~mm}$.

En la práctica, la longitud de las fibras es inferior a las que se emplean en hormigón no proyectado. Típicamente tienen $30 \mathrm{~mm}$ de longitud y $0,5 \mathrm{~mm}$ de diámetro. Se añaden en proporción comprendida entre 30 y $80 \mathrm{~kg} / \mathrm{m}^{3}$. En España se han empleado en dosis de $40 \mathrm{~kg} / \mathrm{m}^{3}$ (túneles del AVE en el tramo Brazatortas-Córdoba) a $60 \mathrm{~kg} / \mathrm{m}^{3}$ (túneles de la Floresta, Barcelona) (14), descendiendo últimamente a $30 \mathrm{~kg} / \mathrm{m}^{3}$. A escala internacional, se emplean dosis entre 50 y $60 \mathrm{~kg} / \mathrm{m}^{3}$. En Japón se ha llegado a colocar, en varias obras de sostenimiento en túneles, $80 \mathrm{~kg} / \mathrm{m}^{3}$ de fibra de $30 \mathrm{~mm}$ de longitud y 0,5 ó $0,8 \mathrm{~mm}$ de diámetro. En Noruega se han llegado a colocar $115 \mathrm{~kg} / \mathrm{m}^{3}$ en un túnel carretero de Oslo (eje transversal E18).

Por su parte, es recomendable que el diámetro del conducto sea mayor o igual a 2,5 veces el tamaño máximo del árido. El tamaño máximo también depende del espesor de la placa a aplicar y de las dimensiones de la malla de refuerzo, caso de usarse ésta.

Generalmente, los fabricantes de equipos suelen recomendar una granulometría para el árido conjunto. En caso de no disponer de este dato, puede partirse de los husos granulométricos recomendados por el ACI-506/85 (1) y que se detallan en la Tabla 7 . El huso $1^{\circ}$ gives us an upper limit both for maximum size of aggregate and fibers length. As a rule fiber length wouldn't be larger than one half of duct diameter. Fibers for shotcrete have a length smaller than normal so, being $30 \mathrm{~mm}$ an advisable value. Aspect ratio is also smaller to avoid rebound, and fiber diameters generally used are 0.8 or $1 \mathrm{~mm}$.

In the field, fiber length is generally $30 \mathrm{~mm}$, and its fiber diameter is larger or equal than $0.5 \mathrm{~mm}$. Fibers are added at a rate between 30 and $80 \mathrm{~kg} / \mathrm{m}^{3}$. In Spain. a rate of $40 \mathrm{~kg} / \mathrm{m}^{3}$ has been frequently used (tunnels for high speed railway line Madrid-Sevilla, between Brazatortas and (órdoba) and $60 \mathrm{~kg} / \mathrm{m}^{3}$ sometimes (Floresta tunnels in Barcelona) (14), going down to 30 $\mathrm{kg} / \mathrm{m}^{3}$ recently. In the world, ratios between 50 and 60 $\mathrm{kg} / \mathrm{m}^{3}$ are normally used. In some supports for tunnels in Japan, $80 \mathrm{~kg} / \mathrm{m}^{3}$ of fibers with $30 \mathrm{~mm}$ length and 0.5 or $0.8 \mathrm{~mm}$ diameter have been placed. In Norway, 115 $\mathrm{kg} / \mathrm{m}^{3}$ have been reached to place in a road tunnel in Oslo (E18 cross axis).

On the other hand, it 's advisable duct diameter be larger or equal to 2.5 times the maximum size of aggregate. Maximum size also depends on thickness of support to place and size of welded mesh, if the last is used.

Manufacturers of shotcreting equipment usually suggests some size gradation for aggregates. If it's not available, gradation zones brought from ACI-506/85 (1), and put in Table 7, can be used. The first zone concerns with mortar, and it can be used for a first layer stuck to

TABLA 7 (TABLE 7)

Gramulometrías recomendadas para hormigón y mortero proyectado (ACI-506) (Recommended gradation for shooted concrete and mortar (A( ' l-506))

\begin{tabular}{|c|c|c|c|c||}
\hline \multirow{2}{*}{$\begin{array}{c}\text { TAMICES (SIEVES) } \\
\text { malla cuadrada } \\
\text { (square mesh) }\end{array}$} & $\begin{array}{c}\text { LUZ DE MALLA } \\
\text { (SIZE OF MESH) } \\
(\mathrm{mm})\end{array}$ & \multicolumn{2}{|c|}{$\%$ EN PESO QUE PASA (\% PASSING BY WEI(iHT) } \\
\cline { 3 - 5 } & 19 & $D_{\max } 9,5 \mathrm{~mm}$ & $\mathrm{D}_{\max } 12,5 \mathrm{~mm}$ & $\mathrm{D}_{\max } 19 \mathrm{~mm}$ \\
\hline $3 / 4 "$ & 12 & & & 100 \\
\hline $1 / 2 "$ & 10 & & 100 & $80-95$ \\
\hline $3 / 8 "$ & 4,75 & 100 & $90-100$ & $70-90$ \\
\hline núm. 4 & 2,40 & $95-100$ & $70-85$ & $50-70$ \\
\hline núm. 8 & 1,20 & $80-100$ & $50-70$ & $35-55$ \\
\hline núm 16 & 0,60 & $50-85$ & $35-55$ & $20-40$ \\
\hline núm. 30 & 0,30 & $25-60$ & $20-35$ & $10-30$ \\
\hline núm. 50 & 0,15 & $10-30$ & $8-20$ & $5-17$ \\
\hline núm. 100 & & $2-10$ & $2-10$ & $2-10$ \\
\hline
\end{tabular}


corresponde a mortero y puede ser válido para proyectar una primera capa de agarre a la base; El $2^{\circ}$ es el más usado corrientemente, y el $3^{\circ}$ sólo puede usarse con grandes espesores, no favoreciendo la inclusión de fibras.

\subsection{Vía humeda}

Es necesario evitar que los erizos que eventualmente se formen en el preamasado entren en el tubo. Para ello debe disponerse una malla de alambre de acero que permita tamizar las fibras antes de su entrada en la bomba; si las fibras son encoladas puede que esto no sea necesario. No conviene bombear el hormigón con exceso de agua ya que, bajo la presión de la bomba, el agua puede migrar arrastrando finos y dejando desnudas la gravilla y las fibras. La consistencia necesaria no permite, en ocasiones, que el hormigón se adhiera a la superficie de trabajo cuando ésta es vertical o se trata del techo. Esta pérdida puede reducirse añadiendo un acelerante a la salida del producto por la boquilla o por el empleo de adiciones puzolánicas o microsílice que favorecen la adherencia. Un contenido de agua excesivo favorece el descuelgue de la masa y una escasez de la misma impide un correcto agarre al soporte.

En general, debe tenderse a la parte más fina de los husos cuando el hormigón se proyecte en clave, pudiéndose admitir más fracción gruesa con proyección horizontal o hacia abajo. Si el HRFA por vía húmeda es bombeado, debe vigilarse el cumplimiento del huso granulométrico especialmente en la fracción fina. $\mathrm{ACI}$ (2) sugiere que de un 15 al $30 \%$ de la arena debe pasar por el tamiz $n^{\circ} 50(300 \mu)$, y del 5 al $10 \%$ por el tamiz $n^{\circ} 100(150 \mu)$ incluyendo en ésta el cemento en exceso a $275 \mathrm{~kg} / \mathrm{m}^{3}$. El módulo de finura de la arena debe estar comprendido entre 2,40 y 3,00 $\pm 0,2$. La proporción en volúmen de conjunto de árido grueso seco compactado al total de hormigón depende de su tamaño máximo y el módulo de finura de la arena. ACI 304 (2) propone la misma tabla que para hormigón normal ampliada a un tamaño máximo de $1 / 4 "(6,35 \mathrm{~mm})$, y que se incluye en la Tabla 8 ground support. The second zone is the most commonly used; and the third is only valid for thicker thicknesses and it doesn't help to include fibers in the mix.

\subsection{Wet mix}

It's necessary to avoid fiber balls formed in prebatching to get into the duct. So an adequate steel mesh to sieve the fibers must be put before the pump; if fibers are collated, it cannot be necessary. Concrete to pump must not have much too water volume as, under pump pressure, fibers and coarse aggregate can be washed out. Sometimes, consistency needed to pump doesn't let concrete stick to ground support when this is vertical or is on top of the tunnel. It can be solved by adding an accelerating admixture at the nozzle, or by adding pozzolan additions or microsilica to improve adhesion to support. An excess of water facilitates sloughing, and a lack of it avoids good sticking to support.

Finer zones are better to shoot on top of the tunnel Coarser aggregates are suitable to shoot both horizontally or downwards. If wet mix SFRC is to be pump, finer fraction must be closely assesed. ACI (2) suggests that sand passing through $n^{\circ} 50$ sieve (finer than $300 \mu$ ) must be between 15 and $30 \%$ and sand passing through $n^{\circ} 100$ (finer than $150 \mu$ ) must be between 5 and $10 \%$ including weight of cement in excess from $275 \mathrm{~kg} / \mathrm{m}^{3}$. Fineness modulus of sand must be between 2.40 and 3.00 \pm 0.2. Proportion of dry rodded coarse aggregate volume (including voids between particles) to volume of concrete depends on its maximum size and fineness modulus of sand. A CI 304 (2) proposes the same table as for normal concrete adding a line for maximum size of $1 / 4 "(6.35 \mathrm{~mm})$ and put in Table 8.

TABLA 8 ( (TABLE 8)

Volumen de conjunto de árido grueso seco compactado (2)

(Volume of dry rodded coarse aggregate including voids between particles (2)

\begin{tabular}{||c|c|c|c|c||}
\hline \multirow{2}{*}{$\begin{array}{c}\text { Tamaño máximo del árido } \\
\text { (Maximum size of aggregate) } \\
\text { (mm) }\end{array}$} & \multicolumn{3}{|c|}{$\begin{array}{c}\text { Volumen de conjunto seco compactado de árido grueso por } \\
\text { unidad de volúmen de hormigón } \\
\text { Módulo de finura de la arena: }\end{array}$} \\
& \multicolumn{3}{|c|}{$\begin{array}{c}\text { Mod coarse aggregate by volume unit of concrete) } \\
\text { (Folume of dry modulus of sand): }\end{array}$} \\
\cline { 2 - 5 } & 2,40 & 2,60 & 2,80 & 3,00 \\
\hline 6,35 & 0,50 & 0,48 & 0,46 & 0,44 \\
\hline
\end{tabular}


La relación cemento/árido total en peso debe estar comprendida entre 1:2 y 1:5 en peso, y en morteros 1:2-1:4. El contenido de cemento debe estar entre 350 y $500 \mathrm{~kg} / \mathrm{cm}^{2}$ para morteros, y los valores indicados anteriormente para hormigón (7). Por su parte Vandewalle (14) recomienda una relación a/c de 0,4 a 0,5 .

\subsection{Vía seca}

En la vía seca el agua se suministra como último componente en la boquilla, mediante un anillo difusor adosado a la misma. Se ha observado una mejor humectación y una reducción del rebote si el agua se añade entre 1 y $3 \mathrm{~m}$ antes de que el HM/P salga por la boquilla. Para llegar a todo el material premezciado, la presión del agua debe ser, al menos, $1 \mathrm{~kg} / \mathrm{cm}^{2}$ superior a la del aire comprimido que impulsa el material seco o prehumedecido. Las fibras se añaden en el premezciado al conjunto de cemento y arena, o arena sola, agregando, después, el cemento, aunque se ha diseñado un dispositivo que permite añadir las fibras en la boquilla. El paso final es siempre la adición de la gravilla.

El transporte de los componentes obliga a disponer de mayor caudal de aire comprimido, que tiende a dispersar los componentes del hormigón a la salida por la boquilla, incrementando la pérdida o rebote. Se ha comprobado una reduccion en el rebote si se añade humo de sílice, el cual puede adicionarse de varias formas (13), ya sea en polvo o densificada. La cohesión que aporta el humo de sílice puede ser suficiente para que no sea necesario el uso de acelerantes, incluso con pequeñas cantidades ( $5 \%$ en peso de cemento); en mayor proporción colaborará en la gananacia de resistencias por su acción puzolánica.

También es muy conveniente una prehumectación de la arena hasta un 3-6\% de su peso seco. Por encima de un $6 \%$ puede producirse un fraguado prematuro del cemento (14) en 1 ó 2 horas, si se mezcla previamente con la arena, dando lugar a un bloqueo de los conductos; de esta manera se consigue una reducción del polvo y mayor regularidad en el producto.

Si el caudal y/o presión del aire comprimido es excesivo, se incrementa el porcentaje de fibras que no llegan ni a alcanzar la superficie sobre la que se proyecta. El rebote se reduce si expulsamos el exceso de aire comprimido antes de su salida por la boquilla con el resto de los componentes. La tendencia al rebote de las fibras es muy importante (es normal un $40 \%$ ) (6) y se incrementa con su esbeltez. Debe tenerse en cuenta que el rebote del árido es superior al del cemento y aumenta con el tamaño del árido por lo que, en general, la proporción de cemento/árido sobre el soporte es
Cement to all aggregate ratio by weight must be between 1:2 and 1:5 for shotcrete, and between 1:2 and 1:4 for mortar. Cement content must be between 350 y $500 \mathrm{~kg} / \mathrm{m}^{3}$ for mortars and values pointed above for concrete (7). Vandewalle (14) recommends water/ cement ratio to be between 0.4 and 0.5 .

\subsection{Dry mix}

In dry mix shotcrete, water is added at the nozzle by a spreading ring jointed to it. If water is added 1 to $3 \mathrm{~m}$ before the nozzle, both a better wetting and reduction in rebound can be obtained. For optimum wetting, water pressure must be around $1 \mathrm{~kg} / \mathrm{cm}^{2}$ greater than air pressure conveying dry or prewetting components through the duct. Fibers can be added and premixed along with dry cement and sand, or be added to sand firstly and adding cement afterwards, although a nozzle design exists to add fibers just at this nozzle. The last step is ever to add coarse aggregate.

Conveying components in dry state forces to a greater consumption of compressed air, which allows to increase both loss of material and rebound. It has been proved microsilica reduces rebound, and it can be added in a number of ways (13), as a powder or densified. Microsilica sometimes avoids to reduce rebound by means of adding accelerating admixtures, even when a little amount of microsilica (around $5 \%$ in weight of cement) is added; If microsilica is added at a greater proportion, it will help to gain strength through its pozzolanic activity.

Prewetting of sand at a rate between 3 and $6 \%$ of its dry weight is very advisable. If wetted above $6 \%$. presetting of cement can occur (14) between 1 and 2 hours after both components to mix, so closing the ducts. On the other hand, prewetting reduces powder production and provides with a greater homogeneity in shotcrete.

If flow and/or pressure of compressed air are too much, rebound of fibers will increase even without fibers to reach the ground support. Rebound is reduced if excess of compressed air is allowed to leave before the rest of components to leave from the nozzle. Rebound of fibers is ever important (usually close to $40 \%$ ) (6) and is greater as aspect ratio is greater. It must be taking into account that rebound of aggregate is larger than that for cement; therefore, cement/aggregate on support is greater than that for mix design. Maximum sizes above 
superior a la de la dosificación de origen. No se recomienda usar tamaños máximos superiores a 10 $\mathrm{mm}$, pues el rebote de los granos de tamaño superior a $8 \mathrm{~mm}$ es muy superior al de los inferiores.

La proporción en peso cemento/árido total debe estar entre $1: 3$ y $1: 4$, con una relación $a / c$ de partida de 0,4 (7), Vandewalle (14) señala como límites 0,3 y 0,4 .
$10 \mathrm{~mm}$ are not recommended, because rebound of aggregates larger than $8 \mathrm{~mm}$ is much too big.

Cement/aggregate in weight must be around $1: 3$ or 1:4, and water/cement ratio around 0.4 (7), Vandewalle (14) recommends values between 0.3 and 0.4 .

\section{BIBLIOGRAFÍA}

(1) AMERICAN CONCRETE INSTITUTE: Specification for materials, proportioning and application of shotcrete. Comité 506, informe 2. 1985.

(2) AMERICAN CONCRETE INSTITUTE: Proposed report: Placing Concrete by pumping methods. Comité 304, propuesta de $2^{\circ}$ informe. ACI Materials Journal. vol. 92, nº 4. 1995. págs. 441-464

(3) AENOR: Hormigones con fibras de acero y/o polipropileno. Determinación del indice de tenacidad de resistencia a primera fisura. UNE 83510. 1996.

(4) AMERICAN SOCIETY FOR TESTING MATERIALS: Standard test method for flexural toughness and first-crack strength of fiber reinforced concrete (using beam with third-point loading). vol. 04.02: Concrete and aggregates. Norma C 1018. 1996.

(5) ASSOCIATION FRANÇAISE DU BÉTON: Guide du béton projectè. № 98 bis, Oct. 1977.

(6) BANTHIA, N.; TROTTIER, J.; WOOD, D.; BEAUPRE, D.: Influence of fiber geometry in steel fiber reinforced dry-mix shotcrete. Concrete International, vol. 14, $\mathrm{n}^{\circ}$ 5. 1992. págs 24-28.

(7) CÁNOVAS, M.F.: Hormigón proyectado. Agrupación nacional de constructores de obras (ANCOP). Madrid, 1990.

(8) KRENCHEL, H.: Fibre spacing and specific fibre surface. Fibre reinforced cement and concrete. RILEM Symp.; Neville, A. (ed.): The Construction Press Ltd. 1975.

(9) MOENS, J.; NEMEGEER, D.: Designing fiber reinforced concrete based on toughness characteristics. Concrete international, vol. $13, \mathrm{n}^{\circ} 11,1991$. pags. $38-43$.

(10) MORENO, E.: Evaluación dela resistencia al impacto de proyectiles de armas ligeras sobre hormigón convencional y reforzado con fibras metálicas. Tesis Doctoral presentada en la E.T.S. de Ingenieros de Caminos, C. y P. de Madrid. 1995.

(11) ROUX, J.; CHEMINAIS, J.; RIVALLAIN; G.; MOURAND, C.: Béton projecté par voie séche avec incorporation de fibres. Tunnels et ouvrages souterrains, $n^{\circ}$ 92, Mars-April 1989.

(12) TATNALL, P.C.: Steel fibrous concrete pumped for burst protection. Concrete International, Dec. 1984.

(13) WOLSIEFER, J.; MORGAN, D. R.: Silica fume in shotcrete. Concrete International, vol. 15, nº 4, 1993 , pags. 34-38.

(14) VANDEWALLE, M.: Tunelling the world. $2^{\mathrm{a}}$ edición. N.V. Bekaert S.A. 1992. Zwevegem, Belgium. 